\title{
The Micropolitics of Reform: Gender Quota, Grassroots Associations and the Renewal of Local Elites in Morocco
}

Yasmine Berriane

Preprint version - Article published in the Journal of North African Studies, Volume 20, Issue 3, 2015, p.432-449.

\begin{abstract}
The aim of this article is to contribute to the unpacking of hybrid regimes such as Morocco, showing some of the micro-mechanisms and power dynamics that shape and organize them. To illustrate these processes, the article looks beyond approaches that dismiss the electoral process in authoritarian and hybrid regimes as a mere façade. Instead, attention is paid to the politics of the elections themselves. Through ethnographic material collected in sub-urban neighbourhoods of Casablanca before, during and after the electoral campaign of three female political candidates in Morocco's municipal and communal elections of 2009, two interconnected power relations are analysed: gender relations and representations, and the relationship between local associations and the partisan political sphere. This study shows that a number of recent reforms have contributed to the pluralization of the political sphere in Morocco, opening up new channels through which outsiders such as women and, more generally, individuals with little political experience and capital have been able to enter the political sphere. The article also sheds light, however, on the direct and indirect ways in which this process of inclusion goes hand in hand with the reproduction of norms, representations and control mechanisms that reinforce former power hierarchies.
\end{abstract}

Keywords: Electoral Politics - Hybrid Regimes - Associations - Gender Quota - Socio-political Change - Morocco. 


\section{Introduction}

In hybrid regimes such as that of Morocco, the broad issue of how power is distributed is at the core of current debates on the reform and democratization of the state. ${ }^{1}$ As a constitutional monarchy, Morocco is ruled on the one hand by a king with extensive powers and his team of state officials, referred to as the makhzan, and on the other by an elected parliament and government led by a head of government who is appointed by the monarch following legislative elections. ${ }^{2}$ The relationship between the monarchy and the representatives of the political parties rests upon an implicit political pact and a political culture of compromise and negotiation that has evolved over time (Tozy, 2010, 2008). A similar duality is present at the communal and municipal levels, where the administration of local affairs is taken care of by a hierarchy of appointed local authorities linked to the makhzan and by elected council members holding seats in district and city councils, which are renewed every six years. Within this dual and unequal system, the political inclusion of underrepresented social categories is yet another highly debated dimension of the issue of how power is distributed. For example, women have long been absent from the country's national and local politics, representing fewer than 1 per cent of all political representatives until the end of the 1990s.

Throughout the past two decades, and more recently with the reform of the Constitution that followed the 2011 uprisings, a series of reforms have transferred more power to the elected segment governing the state at both national and local level. Yet the hegemony of the monarch over the political system seems not to have been substantially altered (Maghraoui, 2011). Furthermore, since the official entry of the former parties of the opposition into the government in the late 1990s, political parties have increasingly become synonymous with opportunism, which has greatly contributed to delegitimizing the elected segment of Morocco's political system, leading to low participation rates and a large number of blank votes at elections. ${ }^{3}$ Several initiatives have also been implemented to include

\footnotetext{
${ }^{1}$ The term 'hybrid regimes' refers to political systems situated in the grey zone in which the implementation of both democratic practices such as elections and the reinforcement of the central power can be observed (Diamond, 2002, 21-35). In a recent article, Thierry Desrues (2013) offers an analysis of the hybrid configuration of the Moroccan political regime.

${ }^{2}$ The notion of makhzan has a very broad meaning. It 'is closely associated with monarchy's inner circles of power. The notion has changed over time to mean coercive state apparatus, as well as the education, health care, administration and economic services the state provides' (Maghraoui, 2011, 698). This system is built upon a particular understanding of power that sees the king as the sole supplier of symbols of authority and the main architect of the dominant political culture (Tozy, 1999, 42).

${ }^{3}$ The former parties of the opposition are the Istiqlal, the Socialist Union of Popular Forces (USFP) and the
} 
underrepresented social categories (such as women) in the political sphere, but their participation remains limited and depends greatly on quota measures (Desrues and Kirhlani, 2010).

Elections are a key point in the tacit struggle for power and legitimacy between these different segments and actors. As illustrated by several authors studying electoral authoritarianism, elections can play a central role in maintaining regimes. They enable them to reinforce their legitimacy at both the national and the international level, control the renewal of elected elites, co-opt the opposition and build new alliances (Gandhi and Lust-Okar, 2009; Schedler, 2006; Waterbury, 1997). In the past decade Moroccan representatives of the central power have in fact put much emphasis on their function as 'managers' of political processes such as elections, implementing a variety of new techniques and measures to prove their commitment to change and democratization while legitimating and regulating such political processes (Tozy, 2010, 17).

At the same time, elections are also points at which the spotlight is directed towards the elected. They offer political parties and the candidates representing them avenues by which to legitimate their function before the electorate and show their strength at mobilizing supporters. These are times when party representatives have the opportunity to build new alliances and outsiders to enter the political sphere (Zaki, 2009; Bennani-Chraibi, Catusse and Santucci, 2004). Through media coverage, political campaigns and discussions in the street and workplace, voters are furthermore - at least momentarily - exposed to discourses informing them about the electoral process and the role played by elected representatives. Hence one could argue that electoral campaigns should also be seen as 'an active arena for social construction of political worlds' that participates in 'moulding old or new social meanings' (Herzog, 1987, 559). Elections should therefore be also approached as key points at which power hierarchies may be (re)negotiated and representations (re)defined.

I therefore look beyond approaches that dismiss the electoral process as a mere façade or limit the scope of investigation to the link between elections and democratization. Through a micro-sociological study of Morocco's municipal and communal elections of 2009, I pay attention to the politics of the elections themselves (Lust-Okar, 2006). My aim is to contribute to the unpacking of hybrid regimes, showing some of the concrete micro-mechanisms that 
contribute to maintaining regimes through the implementation of reforms. Both resilience and change are here intimately linked. While I will illustrate the aspects that indicate and explain the persistence of the regime and the reproduction of power hierarchies, I will also shed light on what Janine Clark calls the 'slow change', which she defines as 'the gradual social, economic and political changes at the local level' $(2012,17)$.

I do not envisage this change, however, as a homogeneous and unilateral process, but rather as an ambivalent and complex set of micro-processes through which power relations are being reconfigured. Two main power relations will be at the centre of my demonstration: gender relations and representations, as well as the relationship between local associations and the partisan political sphere. I will show that a number of recent reforms have contributed to the pluralization of the political sphere in Morocco, opening up new channels through which outsiders such as women and, more generally, individuals with little political experience and capital have been able to enter the political sphere. I also shed light on the direct and indirect ways in which this process of inclusion goes hand in hand with the reproduction of norms, representations and control mechanisms that contribute to reinforcing former power hierarchies.

To illustrate these ambivalent reconfigurations I use ethnographic material collected in situ before, during and immediately after the electoral campaign of three female political candidates living in different suburban working class neighbourhoods in Casablanca, Morocco's largest city and economic capital. ${ }^{4}$ The municipal elections of 2009 coincided with several reforms and top-down initiatives. They took place four years after the launch of the National Initiative for Human Development (INDH) in 2005, which has led to the increased inclusion of civil society representatives in local politics. Secondly, gender quota policies were implemented for the first time at the local level during these elections. These measures were aimed at ensuring a female representation of at least 12 per cent in local councils. Finally, these elections were part of a broader program designed by the Ministry of Interior to modernize and optimize municipal and communal governments, which were given additional prerogatives in the new Communal Charter of 2008.

\footnotetext{
${ }^{4}$ The campaign lasted eleven days, ending on June $11^{\text {th }} 2009$, the day before the polls. This research took place after I had completed 13 months of fieldwork (from 2006 to 2009) for my PhD thesis, amongst thirty women who had managed to become leaders of local associations in several neighbourhoods of Casablanca.
} 
The three candidates, whose campaign I have followed, are named Sana, Habiba and Farida. ${ }^{5}$ They originated from low-income families and live in the rather poor working-class neighbourhoods in Casablanca to which their parents moved in the 1940s and 1950s as part of the rural exodus that took place during that period. Sana is a 42 -year-old university graduate. She is not married, lives with her mother and sister and was unemployed for many years before finding work as the local coordinator of a women's centre created in the neighbourhood by an international organization in 1999, later becoming the president of a local association specializing in social services and education for women. Her neighbourhood is on the periphery of Casablanca where different waves of rural migrants arriving in the city have contributed to the development of many shantytowns between low-income apartment buildings. Farida, who is around 50 years old, moved into this same neighbourhood a few years ago with her family. She dropped out of school at sixteen and has been a housewife for the past 20 years while her husband works as a mechanic for a public transport company. In 2006 she created a local association that offers sports training to the children of the neighbourhood. Habiba is 44 years old. She lives not far from Sana and Farida, in a nearby suburban and predominantly industrial neighbourhood to which she returned with her son after her divorce and where she leads a small local kindergarten. She has been a member of a leftist party since 2004 and is actively involved in an association promoting Amazigh culture and a local association offering sewing classes to the women in the neighbourhood.

As my demonstration will be mainly based on ethnographic material, I have chosen to also organise the article along three main stages of the electoral process. The first (contextual) section describes the main changes introduced into the electoral code before the municipal and communal elections of 2009. The second section focuses on the selection of the candidates, shedding light on the main assets of the three women I followed during the campaign. The third and fourth sections are based on material collected during the campaign, first analysing the gendered distribution of tasks and spaces and then studying the arguments put forward by the candidates.

\section{Changes in the Electoral Code of 2009: A New Ballot System and Gender Quota}

\section{Measures}

The municipal and communal elections of 2009 are characterized by the implementation of a

\footnotetext{
${ }^{5}$ The names used in this article are fictional. They were chosen in order to preserve the anonymity of the person.
} 
series of reforms. Since the first local elections that took place in the 1960s, the status of local representatives has known several reforms and changes. This was particularly the case after the reform of the Communal Charter in 2002, amended in 2008, which 'enlarges the responsibilities of the councils, establishes a legal status for the councillors, and gives a special status to the big urban areas' (Bergh, 2010, 743). ${ }^{6}$ In cities of more than 500,000 inhabitants all the municipalities were melded into one while city councils and arrondissement councils were introduced. As a result of this reform the former 29 municipalities of Casablanca, a city of almost 3 million inhabitants, were merged into one with sixteen arrondissement councils led by 131 city councillors, who are elected every six years (Catusse, Catedra and Idrissi Janati, 2007).

The new Communal Charter also introduced a new ballot system: in towns with a population of over 25,000 (35,000 since 2008) proportional representation was adopted in 2002 through the introduction of a closed party list voting system. ${ }^{7}$ Each party puts up a list with the same number of candidates as the number of seats in each arrondissement and after the vote receives seats in proportion to its share of the vote. These seats are allocated to the candidates on the list according to their order of appearance: the higher a candidate is on the party's list the higher his/her chances are of winning a seat. Accordingly the candidate with the highest chances of winning a seat is at the top of the list. He (or more rarely she) is known as 'head of the list'. These changes were first put into practice in the 2003 local elections, in which neither Habiba nor Farida participated. Sana acted as the supporter of a male candidate who was an influential local entrepreneur. The percentage of women who won a seat in these elections was very low with fewer than 1 per cent women elected to local councils.

Moroccan feminist organizations have been calling for the introduction of quota measures since the 1990s, but it was only in the early 2000s that the issue found its way into king Mohammed VI's official declarations and reforms and that a combination of formal and informal measures was applied to include more women in the political sphere. The first quota system aimed at increasing women's representation in political institutions in Morocco was implemented in the parliamentary elections of 2002 to ensure the representation of at least 10 per cent women (Darhour and Dahlerup, 2013). At the local level a similar quota system was established for the first time at the communal and municipal elections of 2009. New

\footnotetext{
${ }^{6}$ The responsibilities of local representatives were particularly enlarged in the fields of local development in terms of social infrastructure, housing projects, the enhancement of local economy and taxation.

${ }^{7}$ Unlike cities of less than 25,000 inhabitants in which the former first-past-the-post system was maintained.
} 
regulations were inserted into the electoral law introducing 'additional lists' beside the regular ones.

In cities of more than 500,000 inhabitants such as Casablanca, this meant that political parties had to put up the usual list of local candidates as well as a list containing the names of four additional candidates in every district. After the polls the number of seats allocated to each additional list was to be proportional to the number of votes gained by the party in the district, a system ultimately guaranteeing that 12 per cent of all local representatives would be elected from the additional list. All political parties then informally agreed to reserve this list for female candidates. In addition, the Fund for the Promotion of Women's Political Participation was set up by the Ministry of Interior to support programs that inform the population about women's political participation and train potential female candidates. A financial bonus was promised to political parties that encouraged women's candidacy. Women's rights organizations offered training sessions with the help of national and international institutions, aimed at preparing women to run for office.

This trend is by no means an exception. Since the 1990s such measures have been spreading worldwide, giving rise to a significant amount of literature analysing the reasons behind the diffusion of gender quotas, discussing its effects on female participation and arguing for or against such measures (Krook, 2009). ${ }^{8}$ A large number of the studies that address gender quota policies in North Africa and the Middle East argue that gender quotas are one of the 'surest ways' (Moghadam, 2009, 25) of overcoming structural and cultural obstacles to women's political representation. However, several other authors have shown that gender quota policies can also be used to reproduce power hierarchies at both the social and the political level. The 'least politically costly and most cosmetic way(s) to show a commitment to democratic development' (Bozena, 2010, 9), gender quotas can be used to reproduce and reinforce pre-existing patriarchal norms and autocratic forms of rule (Sabbagh, 2007; AbouZaid, 2006). Studies on Morocco have shown that they can enable political elites to build new alliances (Sater, 2007) and reinforce their clientelistic networks (Lidell, 2009; Vairel, 2009). In other words, while gender quotas enable women to participate in politics they also tend to contribute to reproducing former power hierarchies. But how concretely is this ambivalent process being shaped? To what extent can the 2009 electoral experiences of Sana, Habiba and

\footnotetext{
${ }^{8}$ Gender quotas have been introduced in several countries in the Arab world in the past decade such as Jordan, Egypt (abandoned in 2012), Morocco, Palestine, Mauritania, Sudan, Iraq and Tunisia.
} 
Farida shed light on this?

\section{Becoming a Candidate: New Channels to the Political Sphere?}

These reforms have opened up new channels via which outsiders, whose background does not provide them with the necessary resources to enter the political sphere, to become political candidates. The implementation of gender quotas in 2009 had in fact a significant impact on the trajectories of Sana, Habiba and Farida. Many months before the start of the campaign, several political parties approached them, offering them places not only as candidates but also at the head of their additional lists. This is all the more striking as none of them had had any substantial political experience prior to these municipal elections. Apart from Habiba, none of the candidates I met in 2009 had been members of a political party before.

In their search for female candidates, local sections of the parties were clearly ready to recruit women regardless of previous political experience and ideological adherence, a reminder of both their lack of sufficient female membership and the secondary role played by ideology and party labels. While being female had long been an obstacle in Morocco's local political sphere, in 2009 it became a clear asset and resource for all those who, like Sana, Habiba and Farida, were interested in entering the political sphere. The number of female candidates almost quadrupled between 2003 and 2009, representing 15.7 per cent of all candidacies and the number of elected female representatives increased to 12.25 per cent of the total, a result that has been highlighted nationally and internationally as a clear sign of Morocco's move towards a more egalitarian political system (Barakat, 2009).

Sana was approached by five different parties including the Islamist Justice and Development Party (PJD) and its fiercest opponent, the Authenticity and Modernity Party (PAM), which was created just before the 2009 elections by Fouad Ali El Himma, who is said to be a close friend of the king ${ }^{9}$. She chose to run as head of the National Rally of Independents' (RNI) local additional list, a list with a very good chance of winning many seats in the district as it was headed by the then acting president of the local council. ${ }^{10}$ Farida ran as a candidate on the local additional list of the Constitutional Union (UC), whose regular local list was headed by

\footnotetext{
${ }^{9}$ Since 1997 the PJD has progressively imposed itself on the Moroccan political sphere as a moderate Islamist party and won the legislative elections in 2011. Its results in 2009 were very strong as it came in third in Casablanca and fifth nationally. As for the newly created PAM, it won the highest number of seats in 2009.

${ }^{10}$ The RNI was created in 1978 by the brother-in-law of Hassan II. It is said to be a party of notables and is not particularly critical of the establishment. In 2009 it won the elections in Sana's district, coming in third nationally.
} 
an influential member of the local council and which had a moderate chance of winning a few seats. ${ }^{11}$ While Sana and Farida entered the political campaign with no political experience, Habiba campaigned as head of the local additional list of the Party of Progress and Socialism (PPS), a leftist party that she had joined in $2004 .{ }^{12}$ Unlike in past elections, eight women campaigned for the PPS in the district that year: four in the additional and four in the regular list.

Thus in 2009 being a woman was a clear advantage for Sana, Farida and Habiba, who found themselves selected as candidates. However, this was not their only asset: being leaders of local associations was also significant. It is because they were women and leaders of local associations that Sana, Habiba and Farida attracted the attention of several political parties and were offered candidacies at the head of additional lists. ${ }^{13}$ As mentioned, Sana entered the associational sphere in 1999 as local coordinator of an international organization specializing in development programmes. A few years later she became well-known in her neighbourhood as president of a local women's association. Habiba entered the associational sphere in 2004 through a local association specializing in promoting Amazigh culture. The seven female candidates who ran in the same electoral list with her in 2009 were all involved in the same association, which offered training in handicrafts and supported applications for micro-credit. Encouraged by the local authorities, in 2006 Farida, herself a former athlete, created a local athletics association and has since become a popular figure in the neighbourhood.

While most studies on women's access to political offices in Morocco highlight the importance of family connections in empowering women to participate in political parties, public affairs and electoral campaigns (Lidell, 2009, 83; Vairel, 2009, 148; Sater, 2007, 736), the trajectories of the three women show that new gateways to local political positions have emerged. Among these the associational sphere holds a predominant position. ${ }^{14}$ The cases of the three candidates are by no means exceptional. As the press reported after the 2009 elections, a substantial number of all female candidates were involved in associations (Filali-

\footnotetext{
${ }^{11}$ The UC was created in 1983. It is said to be liberal on economic and conservative on social issues. In Farida's district it won only one seat in 2009 and was seventh at the national level.

12 The PPS is the heir of the former Communist Party. Its representatives have been involved in Morocco's government since 1998. It used to be well-represented in Habiba's district but in 2009 it faced a strong local PJD list.

${ }^{13}$ I use the term 'association' (jam iyya) here rather than NGO because the distinction between most of these organisations and governmental institutions is rather indefinite. By association I mean registered organisations that fall under the 1958 Code of Public Liberties.

${ }^{14}$ Other avenues include professions that offer daily contact with the population such as schoolteacher, nurse, doctor, wedding organiser, shop owner, etc.
} 
Ansary, 2009). This is confirmed by an unpublished empirical study commissioned by Morocco's Ministry of Interior and USAID in 2010: almost 60 per cent of the female candidates who won a seat during the 2009 elections in the regions of Doukkala-Abda and Fès-Boulemane declared that they had been actively involved in an association prior to their candidacy. The authors of the study conclude that in 2009 the involvement of female candidates in associations was a clear asset in favour of their candidacy (Royaume du Maroc and USAID, 2010, 46-47).

Leaders of associations are generally considered experienced in addressing and mobilizing people but also as having far-reaching local networks that enable them to attract a substantial number of voters, mainly among the beneficiaries of their organization. As predominant gender representations tend to portray women as unfit for political office, their experience in an association is furthermore seen and highlighted, far more than it is for men, as valuable training through which they acquire the necessary skills to become politicians. ${ }^{15}$ Their experience in an association therefore not only enabled Sana, Habiba and Farida to substantially develop their social network, gain popularity at the local level and become more experienced in mobilizing and addressing people; it also contributed to producing an image of them as women fit and qualified for political office.

Their activities as association leaders also facilitated the organization of the electoral campaign. The association was used as a space in which the candidates started campaigning long before the official start of the electoral process. Literacy, sewing and cooking classes were used as platforms from which the beneficiaries were informed about the candidacy plans of one or several leaders of the association. Furthermore, as leaders of an association the women were able to recruit organization employees as supporters and intermediaries and to identify, from their list of beneficiaries, which households to visit during their campaign. The activities of their association were also very much in evidence in their electoral speeches, as discussed in the last section of this article. Associations play therefore a key role in today's elections in Morocco. The involvement in an association offers the necessary social capital to individuals whose background does not provide them with the necessary resources (notability, gender, education, financial means

\footnotetext{
15 Much less importance is attached to male candidates' political competence. Whereas men are generally considered as being naturally suited to political office, women are perceived as naturally lacking the desired qualities and therefore, they need to do more to qualify. Similar observations were made, in Morocco, by Leila Bouasria (forthcoming) in her study of the selection of female candidates during the legislative elections of 2011.
} 
and/or social contacts) to enter the political sphere.

The involvement of association leaders in the political sphere is neither new nor a genderspecific phenomenon. Since the end of the 1990s civil-society actors have gradually become significant local players and have entered the electoral process in Morocco (Iraki, 2005), as well as other countries of the Arab world (Ben Nefissa, 2002). However, this tendency was greatly strengthened in the $2000 \mathrm{~s}$ through the increased number and importance of associations in Morocco. ${ }^{16}$ This recent increase resulted mainly from development programmes such as the INDH, a national initiative launched by King Mohammed VI in 2005 as one of his long-term projects to fight poverty, illiteracy and social exclusion in certain rural and urban areas, including the neighbourhoods of the three female candidates discussed here. ${ }^{17}$ The INDH included associations as key organizations representing the interests of local populations and participating in designing and implementing local development projects (Bono, 2010; Berriane, 2010).

This led to the increase of a particular type of association such as those represented by Sana, Farida and Habiba: small, locally-based and formally apolitical grassroots organizations specializing in social, developmental and educational issues and targeting mainly women and young people. This process was coupled with the growing number of female association leaders whose inclusion in the implementation of development projects was particularly encouraged by the INDH guidelines (Berriane, 2013). Sana received enough funds from the INDH to finance several development projects and create a multipurpose centre for women and young people offering literacy classes, and professional training. The association in which Habiba and her seven running-mates were involved received a grant from the INDH in 2007 which enabled it to buy new sewing equipment and offer training to an increasing number of beneficiaries. A year after creating her association, Farida received a small grant from the INDH to renovate and equip an old school for use as a training centre.

It is therefore important to note that some of the changes that were noticeable during the 2009 elections are closely linked to transformations that had started much earlier, following policies implemented since the beginning of the 2000s. Sana, Habiba and Farida's places at the top of

\footnotetext{
${ }^{16}$ According to official estimations published in 2011, there were almost 45,000 associations in 2007 (Haut Commissariat au Plan, 2011,9)

${ }^{17}$ As a matter of fact the king 'has defined the INDH at several occasions as his own "revolution of the king and the people", calling for an actualisation of the "symbiosis" between the throne and the population'. (Bono, 2010: 21-22).
} 
the local additional list of parties that had a high chance of winning the local elections depended on their popularity as association representatives and their presumed ability to mobilize an important number of beneficiaries. In turn, this depended largely on their capacity to access public central government funds in order to be able to offer attractive services and programmes. ${ }^{18}$ It even appears that association leaders' chances of being picked by parties with a good chance of winning many seats depended largely on the size of the funds gathered, for instance via the INDH. Thus, Sana, the highly successful president of a local association, was offered a place at the head of the additional list of the party with the highest chances of winning the election in the district and with the capacity of financing her campaign. Her neighbour Farida, who had received less financial support through the INDH and was struggling to implement the project she had received the funds for, was only approached by parties with a smaller chance of winning seats in the council and received almost no financial support during campaign. This had, in turn, an impact on the turnout of the elections: Sana eventually won a seat in the local council; Farida did not. Consequently we can argue that there is a correlation between the popularity gained by association leaders via the support provided by the state and their chances to actually win elections.

The key role of associations and state run programmes such as the INDH in the electoral process opens up new interrogations and hypotheses about the mechanisms through which the political regime is being maintained and oppositions contained. The process through which individuals have to go when planning to create an association enables representatives of the Ministry of Interior to filter out those they deem unsuitable, such as members of the Adl-WalIhsane movement for instance (Berriane, 2010, 100-101). If the local authorities' enquiry raises doubts about an applicant's political objectives $\mathrm{s} / \mathrm{he}$ is denied the receipt that proves that they have registered their organization. The INDH selection process represents yet another channel through which unwanted associations can be weakened by denying them access to the resources that the initiative makes available. Applications for funding submitted by associations go through a complex and rather opaque selection process involving local committees, headed by elected district presidents, and later by regional committees headed by appointed governors which select the projects and organizations to be funded.

The case of the three candidates shows how both the introduction of gender quota measures

\footnotetext{
${ }^{18}$ Most of the local associations that I encountered during my fieldwork did not have access to international funding but can apply for funds offered by the state through programs such as the INDH.
} 
and the implementation of policies that promote the development of grassroots associations have contributed to a renewal of the channels that lead to political participation. Former outsiders (such as women) have thus been able to enter the political sphere. In the meantime, the top-down promotion of a certain kind of association (preferably non politicized ones) and the distribution of resources through programmes such as the INDH indirectly shaped the 2009 elections by contributing to the emergence of new association elites to which the necessary means of becoming locally influential were given. Yet, the increasing number of association leaders within the electoral lists that accompanies this process can however also be interpreted as an indirect method by which the ruling elite has the opportunity to regulate elections long before campaigning even starts; thereby contributing to reinforcing the status quo within the regime.

\section{Campaigning indoors: private female gatherings as alternative electoral spaces?}

Whereas the process that has led to the selection of the three candidates in 2009 shows the emergence of new avenues to the political sphere, the ways they campaigned indicate the development of alternative electoral spaces. In order to better illustrate this point, let me first describe one afternoon spent with Habiba and her fellow candidates in Amina's house.

Women have started gathering in the small living room where I am sitting with Habiba, the head of the local PPS additional list. Two tables have been set with a wide variety of sweets and juices. Chairs have been added to the simple traditional sofas to create more seating space for the growing number of women entering the room, greeting us and taking a seat. Each is warmly welcomed by today's host, Amina, who wears a gleaming smile, a caftan and a headscarf wrapping her hair like a turban. Amina is a local wedding planner and one of Habiba's fellow electoral candidates. The room is full of women of all ages from Amina's friends, clients and neighbours. Most of the female candidates of the local PPS list are also present. The first part of the discussion revolves mostly around the qualities of a perfect husband while Amina offers coffee and tea and serves sweets. The general tone of the conversation is cheerful, although some of the guests do not participate in the discussion, waiting silently for the second part of the meeting.

Whereas the first part of the reunion resembles a convivial gathering of friends, the second part becomes much more formal. Habiba and some of her fellow candidates make short speeches in which they promise substantial changes and encourage the guests to vote for their 
local list of candidates. The speeches are followed by an open floor for questions and recriminations directed at Habiba and her fellow candidates. A certain tension is now clearly palpable. The work of former district members is criticized: promises have not been kept, politicians have been found to be corrupt and the neighbourhood is still suffering from many problems. Why should it be any different this time? While Habiba and her fellow candidates are engaged in answering these questions the hostess keeps a vigilant eye on everyone's plate and glass, refilling them where necessary and occasionally intervening with a joke to lighten the general mood.

One of the reasons given for women's under-representation in Morocco's political sphere is that 'electoral campaigns take place in areas that are reserved for men, such as public cafés' (Sater, 2007, 731). But, as illustrated by the case of the three candidates that I have accompanied, an essential part of each electoral campaign takes place behind the scenes in informal and private settings that are usually much more accessible to women than to men. This kind of small and casual gathering of a maximum of 20 people takes place at the home of the hostess, a supporter, intermediary or candidate, and can last from an hour to a whole afternoon. The guests are all welcomed as if they were friends invited to share a convivial time with their hostess. The refreshments are usually sponsored by the candidate, the party or the head of the main list, who usually finances most of the campaign. The idea behind these gatherings is that each woman attending has in turn the capacity to enlist many other people, mainly from among her family, friends and neighbours.

The form, size and number of these meetings differed, largely dependent on the amount of financial support for the candidate and the way each campaign was organized. These contrasting experiences highlight the differences that result from an association leaders' capacity to attract the attention of influential parties. Farida, who received little financial and almost no organizational support from the party she was representing, mainly campaigned alone, visiting female friends, neighbours and beneficiaries of her association or stopping by schools and shops. Habiba and her colleagues received financial support from the main heads of their electoral list, but that was rather limited. Thus each of the eight female candidates of the local PPS list arranged a meeting at home. Sana's campaign was fully-funded and organized by the two main local candidates, who were male and well-off, and their team of local intermediaries. With a rented car at her disposal she would drive from one meeting to the next, attending up to four or five pre-planned gatherings a day. These reunions took place 
in the homes of local inhabitants who acted as mediators and supporters in their neighbourhood in exchange for a financial remuneration.

The male heads of the electoral lists attended similar reunions: women's meetings organized by female supporters as well as mixed private and public gatherings. At the same time they also headed big processions through the different district neighbourhoods, chanting party slogans, distributing flyers and talking to passers-by. The participation of female candidates during these processions was rather limited. Sana did not speak in front of mixed crowds or participate in the processions headed by the male main candidates on her list. Farida joined the processions from time to time, accompanying the crowd of supporters following the male candidate. Habiba and some of her fellow running-mates accompanied the male main candidates during their processions, always walking behind the group of men. Their participation in these walks was, however, a recurrent topic of disagreement between the female and male candidates because most of Habiba's female running-mates did not feel at ease during these processions, clearly preferring to limit their participation to women's meetings.

The question of security was a recurrent argument put forward by most of my interlocutors, male and female, to explain why female candidates avoided public and mixed gatherings. Paradoxically, the recurrent discourse on the 'dangers' faced by women in the public sphere contrasts greatly with their actual practice as leaders of associations who managed to overcome many of the gender boundaries that hindered them from participating fully in the associational sphere. They frequent spaces in which male and female representatives of associations interact publicly, attend meetings that start late in the evening and often travel to other cities for training and conferences (Berriane, 2013). However, during electoral campaigns these experiences seem to fade and boundaries that these women had previously managed to overcome re-emerged, unquestioned by almost all of the male and female candidates that I met in 2009.

The way male and female candidates were portrayed during the campaigns I observed in 2009 was thus very different. Male candidates addressed all the inhabitants of the neighbourhood at private gatherings, public meetings and processions. Hence they were portrayed as potential representatives of all the citizens in the district. At the same time, the women mainly performed at private gatherings and to only one sector of society: females. This gendered distribution of electoral spaces and roles clearly reproduces social and cultural constructions 
that stress men's capacity to act as representatives of all citizens while denying women's ability to do so.

There are many reasons for the three candidates' readiness to accept the segregated way in which they campaigned. Campaigning indoors and in spaces frequented only by women has some clear advantages. First of all, it is a more convenient and less tiring and physically challenging way to campaign, a factor that the three candidates that I accompanied mentioned frequently. Second, the female candidates considered private meetings the most efficient campaign tool at their disposal. While public gatherings are used to inform as many people as possible about the existence of the local list and its main candidates, private gatherings are used to get closer to the voters, address potential topics of discontent, form new alliances through promises made in private and persuade local intermediaries to mobilize people in their own entourages. Thus Sana explained to me: 'We didn't waste time participating in the men's convoys. Our campaign took place directly in the people's homes. People we know. This is where you do most of the work'. Sana's explanation is all the more telling as she was the most successful among the three candidates while being also the only one who campaigned exclusively in private gatherings.

Thus it would be too reductive to limit the women's meetings described above to their private and gender-segmented dimension. As clearly shown by Yadav's analysis of Islamist women's activism in Yemen, spatial segregation does not entail 'seclusion from the public'. While the women's meetings held by the candidates I accompanied in 2009 were 'spatially private' they were 'substantively public in intent and effect' (Yadav, 2012, 1). These gatherings play multiple roles that have direct public effects. They enable women who have difficulty accessing public and male-dominated spaces, in which most of the public part of the campaign takes place, to access information concerning the electoral process and the political campaign while offering an arena in which they can express their concerns and demands to local candidates. In the informal, convivial and festive character of these meetings, the political character of electoral campaigns gets blurred, which seems to attenuate potential antagonism towards political candidates, creating an atmosphere that is much more conducive to the diffusion of political messages and the building of local alliances. Furthermore, these meetings were arenas in which the three candidates were able to diffuse a discourse based on the idea of renewal of the political sphere through the inclusion of women and association leaders, whom they described as 'new entrants' uncorrupted by any political experience. This 
discourse has important political implications: while it aims at (re)building citizens' trust in the political process, it also contributes - as we will see now - to reproducing the image of corrupted (male) politicians.

\section{Campaigning in the Name of Women, Associations and the King}

The speeches made by the three candidates during the campaign showed some interesting similarities. Insisting both on their specific qualities as women and on the particular skills and resources gained from their experience as association leaders, they were able to promise a renewal of the political elite. The following scene observed during a women's meeting held by Sana will enable me to both illustrate this idea and show the many implications of this discourse.

Sana is surrounded by two of her campaign assistants and a group of 20 women who have been invited to join the women's meeting organized by Fatna, who lives in a small house in one of the many shanty towns in the district. We are all sitting on old rugs spread on the ground in her house's courtyard. The tension is much stronger than that of a few days earlier in the meeting at Amina's house described above. The general animosity is directed against B., the president of the district council who is heading the local RNI list and on whose additional women's list Sana happens to be. As claimed by his opponents, many of the promises B. has made during previous campaigns have never been fulfilled. He has not solved the problem of unemployment in the neighbourhood. The garbage is not collected on a regular basis. Insecurity is rising. As for the programme to resettle the inhabitants of the shanty towns into low-budget housing projects, it is facing many problems and irregularities.

Sana faces a difficult task. She has to convince the potential voters sitting in front of her that they should still vote for an electoral list headed by B. She starts her speech by distancing herself from the common practice of making false promises during political campaigns.

Thank you all for coming today. I am not here to tell you that I will solve all your problems. I am not going to make any promises I cannot fulfil. I am not going to tell you that I will find jobs for everyone.

Very few of the women present at the meeting seem to be listening to her words. Most of them are chatting with each other, quite demonstratively indicating that their interest in the candidate's words is limited. One of the women exclaims: 
Last time B. came here I helped him during the campaign. He made so many promises. And then he disappeared. Look how things are around you! There is no light in the street! We're scared to leave the house when it is dark. No one comes to pick up our garbage!

After a short break, during which Sana seems disconcerted, she continues her speech, trying to build a bridge between herself and the inhabitants of the neighbourhood:

I was born here and I grew up here. I'm from your neighbourhood. I went to school here and then to university. I got my first degree, but didn't complete my studies. This is when I encountered the problem that many young people of the district encounter: I didn’t find a job. [...] While jobless I decided to be proactive, to find an occupation instead of waiting for the state to do it for me. With some of my friends we took the initiative and we created the first female association of the neighbourhood. We taught women how to read and how to write. We helped them to fill their empty time and to start activities that enable them to earn some money.

Only a few guests are still chatting in the background now. Most women in the audience are listening to Sana's words. It is not so much Sana's trajectory that seems to be attracting their attention but rather the services provided by her association. Several questions are asked about the activities of this organization. Sana appears much more relaxed and confident now. She answers all the questions and adds more details about the association's other activities, such as the help it provides for people who have problems with local public administration. The story of how she helped a single mother to get a birth certificate for her son to enable him to go to school is commented on enthusiastically by the audience. This is when Sana moves to her next argument.

We worked so hard that one day His Majesty the King sent us money. [...] He had heard about the work we were doing in the neighbourhood. He decided to support us. [...] You all know that the king is very powerful. Would he have given me his money had he suspected that I would keep it for myself? He knew that I would redistribute it. And this is what we did. We gave it to people in need. After that we were also given a centre, at which we now train women.

The background chat has stopped completely since Sana mentioned the intervention of the king. The women present at the meeting listen attentively. Some of them are smiling. One 
intervenes to insist on the fact that it is primarily B., the current president of the district council and head of the RNI list that Sana represents, who is the source of their resentment. Several women in the audience are now speaking at once, each describing her own disappointing experience with the current president of the district. Their anger threatens to cloud the general mood again. Sana moves rapidly to her last main argument.

I know that certain things went wrong. But this is why it's time for a woman to enter the council. You know that women always keep their promises. When a woman says she will do something, she does. A woman keeps her feet on the ground and works according to the realities surrounding her. If I get into the district council I'll make sure that things change. [...] Women are the ones who know best what other women need. [...] Women are effective and honest [...] A woman who enters the council for the first time will try to show what she is capable of doing.

This final argument seems to bring a general consensus. Examples illustrating women's integrity while emphasizing men's unreliability are coming from every side until one of the guests finally exclaims:

I wasn't planning on voting this time, but now I will vote in order to have a woman in the council. Why always vote for men? Women are much more capable than men!

Sana relaxes noticeably. She has finally reached her objective.

The scene in Fatna's courtyard is by no means exceptional. Farida, as well as Habiba and her fellow candidates, used similar arguments to convince their audiences. They based most of their campaigns on their specific capacity as both representatives of an association and as women, to renew and enhance the political sphere. While these two lines of argument proved to be effective each time the candidates had to face a reluctant or even dissatisfied audience, they contributed to also reproduce the dividing lines between men and women and between associations and political parties, further delegitimizing the latter.

The first line of argument is referring to women's 'specific' and 'natural' characteristics and skills. The three candidates emphasized women's capacity to empathize with other women, understand their specific problems and be more reliable and less corrupt than men. At the same time, they described men as perfidious, generally dishonest and disinterested in the well- 
being of others. Thus all the female candidates argued that voting for a woman would be the best guarantee of radical change and the best way to break with past corrupt practices while improving and cleaning up local politics. This line of argument provoked vivid reactions and laughter every time from all the women present at the meetings. Even those who had expressed their intention not to vote in the run-up to the elections, based on the many grudges they held against political representatives, agreed on the validity of this point and indicated that this might be a good reason to support a female candidate. In a context in which the mere idea of women's ability to act in political leadership positions is still marginal, the gender argument put forward by the candidates in their campaign raised a certain awareness in their audiences of the importance of including women in the political sphere.

Yet, by referring to stereotypes attached to each gender the candidates also reproduced distinctions that are commonly made between men and women, mainly stressing the latter's specific abilities as housekeepers and child carers and emphasizing their interest in issues linked to their family and immediate environment. Their insistence on men's inadequacies further reproduced the idea that the political sphere is mainly dominated by corrupt politicians reinforcing images that have brought political elites into disrepute in Morocco over the years. Thus one could argue that, paradoxically, the three candidates' use of gender stereotypes that stress women's political qualities and highlight men's inadequacies contributes, at the same time, to delegitimizing the role of elected representatives.

The same idea can be applied to the recurrent distinction made throughout the campaign between 'good' associations and 'bad' political parties. In fact, the three candidates also stressed their role as association leader and emphasized the valuable input of their association, highlighting their active contribution to improving the living conditions of their community. This enabled them to show their ability and willingness to act and commit themselves to the public interest as opposed to the predominant image of corrupt and inefficient politicians who are seen as exclusively concerned advancing their own private interests. This distinction was highlighted throughout the campaign. Rather than focusing on the political party they represented, the campaign as conducted by the three candidates was more like an operation to promote their association and associational life. The services offered by the association and the role played by these organizations locally were usually at the centre of all speeches made by the female candidates. The exception was Habiba who had become member of the party several years before the elections. Throughout the campaign, she tried desperately (and quite 
unsuccessfully) to persuade her fellow candidates to move on from talking about the association to stress the party's programme and importance. Thus, while elections are expected to be points at which the spotlight is directed towards political parties, enabling the latter to legitimate their function before the electorate, the studied examples indicate that political parties tend to almost disappear from campaigns led by association representatives who have just recently joined the party. An increasing number of association leaders within the electoral campaign contributes to moving the spotlight away from parties, directing it towards associational life. References to their association did not only enable the candidates to promise a renewal of the political leadership. It enabled them also to illustrate their privileged relationship with the state through their access to resources that it makes available, holding out the prospect of offering, through their association, special help and services for all supporters who agreed to vote for them. In a context such as Morocco, where 'voters [...] primarily seek to reap patronage benefits' and therefore 'support candidates whom they believe they will deliver advantages to them' (Gandhi and Lust-Okar, 2009, 409), associations become therefore new concrete avenues through which patronage and access to state resources can be promised to voters.

This idea was particularly present in Sana's speeches as she was able to put forward the many projects of her organisation that had been financed by state led programmes such as the INDH. Although Sana distances herself at the beginning of her speech from those candidates who make patronage promises they cannot keep, she ends up making quite similar promises, using the association as an intermediary institution that guarantees that these promises will be held. She insists on the fact that her association has a privileged access to resources made available by the state, holds out to her audience the prospect of generating an income through professional skills that they can acquire in the association she heads and, finally, illustrates how her support - as a mediator - can help overcome problems with local bureaucracies. In Habiba and Farida's speeches, references to resources made available by the state to their association were less prominent, as they had received much less funding by programmes such as the INDH. Yet, both candidates still highlighted the many services they could offer to the population as intermediaries: their privileged access to certain local authorities or the training, medical services or access to microcredits provided by their organisation. While insisting on their capacities both as women and as association leaders to renew the political sphere, they were at the same time, reproducing - through new ways - forms of 'competitive clientelism' 
(Lust, 2009) that dominate the electoral sphere.

Mentioning programmes such as the INDH during the campaign did not only contribute to illustrating the candidate's privileged access to state resources, it went also hand in hand with mentioning the role of the king in the launch and implementation of these programmes. Thus, paradoxically, not only were the political parties almost absent from most speeches, but via the associations it was the monarch - who is theoretically supposed to be counterbalanced by the political parties - who was frequently mentioned and praised throughout the campaign. In light of the hybrid institutional arrangements on which the Moroccan regime rests, this observation is of particular importance. Elections represent not only avenues by which democratic practices aimed at opening up the regime are being implemented. In the current reform-oriented context of Morocco in which state-sponsored association representatives are increasingly entering electoral politics, they represent also avenues by which the image of the king (ie. of the makhzan) as main architect of the country's development and sole supplier of symbols of authority is being reproduced and reinforced.

\section{Conclusion}

The study of Sana, Habiba and Farida's electoral campaigns in 2009 has provided valuable insight into some of the micro-mechanisms that shape hybrid regimes such as that of Morocco, and the ambivalent reconfigurations of both the political regime and its society. The implementation of several pro-participatory policies has opened up new channels and spaces via which outsiders have been able to enter the political sphere. However, this process of inclusion also goes hand in hand with the reproduction of norms, representations and control mechanisms from above that contribute to reinforcing former power hierarchies. This opens up new interrogations and hypotheses about the concrete mechanisms through which the Moroccan political regime and power hierarchies within society are maintained and opposition is contained.

The implementation of gender quota policies in 2009 has transformed gender into a local political resource. The number of female political candidates has increased substantially, making them more visible. As argued by several authors, the mere presence of more women in a formerly male-dominated sphere has the capacity to create gender awareness, alter expectations and initiate the transformation of gendered power relations (Karam and Lovendusky, 2005; Bayat, 2010). As a matter of fact, the gender argument put forward by the candidates during their campaign seemed to raise awareness among their audiences of the 
importance of including women in the political sphere. Private gatherings of women open up new spaces of political sensitization that bring candidates closer to female voters, attenuate tensions, at least momentarily, and enable women who have difficulty accessing public and male-dominated electoral spaces to gather information about the elections and express their concerns. However, this gendered distribution of tasks and spaces clearly reproduces gendered representations that highlight men's capacity to act in the name of all citizens while denying women's ability to do so. This reinforces the prevalent idea that the additional (women's) list is of less value than the regular (men's) list. As a matter of fact, once elected to local councils most elected women were relegated to secondary roles and were rarely offered significant political posts (Filali-Ansary, 2009). Sana, who has suffered greatly from this since she has won a seat in the local council, has decided not to stand as a candidate in 2015.

The recent reforms have also contributed to the increase and reinforcement of local associations specializing in social and developmental issues. As experience within local associations provided its leaders with valuable material and symbolic resources, their female as well as male leaders were particularly courted by political parties in 2009 , increasingly making associations gateways to political positions. Through these intermediary institutions individuals who are not of the traditional local notables have the opportunity to develop their networks and acquire the necessary social and political resources to promise patronage and access to state resources and, thus, to compete with the elites who have previously dominated the local political sphere.

The emergence of association leaders in the electoral process has, however, several other effects that contribute to securing the hegemony of the makhzan over the elected segment governing the state. Processes such as the regularization of the status of an association or the distribution of public funds can be used by the ruling elite to exclude individuals and organizations. Consequently the increased participation of association leaders during elections can also be interpreted as an indirect method by which the ruling elite, and in particular those linked to the makhzan, have the opportunity to regulate elections long before campaigning even starts. Representatives of associations - especially those without former political experience - tend to direct the focus of their electoral speeches on the role of their organization. They either do not mention the party they represent or they transfer the distinction of 'good' and 'efficient' associations versus 'corrupt' and 'inefficient' politicians into the electoral campaign. While this enables them to promise a renewal of the political 
sphere, their campaign reproduces negative representations that delegitimize the elected while shedding positive light on the monarch as the main architect of the country's development strategy.

These micro-processes of reform inform us about both the micro-transformations that we tend to overlook when focusing too much on the idea of resilience, and the many ways through which power hierarchies are partly reproduced and maintained as they are being reformed. While top-down approaches focus mainly on the direct manipulation of elections and cooption of the elite, this study of the three candidate's electoral campaign illustrates how, on very different scales, a plurality of actors participate actively and often indirectly in both transforming society and maintaining the status quo from below.

\section{Sources:}

Abou-Zaid, Gihan. 2006. “The Arab Region: Women's Access to the Decision-Making across the Arab Nation". In Women, Quotas, and Politics, edited by Drude Dahlerup, 168-193. New York: Routledge.

Barakat, Amina. 2009. "Elections communales: le temps des femmes". Inter Press Service, June 22.

Bennani Chraibi, Mounia, Myriam Catusse, and Jean-Claude Santucci, eds. 2004. Scènes et coulisses de l'élection au Maroc. Les législatives 2002. Paris/Aix en Provence: Karthala/IREMAM.

Ben Nefissa, Sarah, ed. 2002. Pouvoirs et associations dans le monde arabe, Paris: CNRS Editions.

Bergh, Sylvia. 2010. "Assessing the Scope for Partnership Between Local Governments and Community-Based Organizations: Findings from Rural Morocco”. International Journal of Public Administration 33 (12), 740-751.

Berriane, Yasmine. 2010. "The Complexities of Inclusive Participatory Governance: The Case of Moroccan Associational Life in the Context of the INDH". Journal of Economic and Social Research 12 (1), 89-111.

Berriane, Yasmine. 2013. Femmes, associations et politique à Casablanca, Rabat: Centre Jacques Berque.

Bouasria Leila. Forthcoming. "The Moroccan Gender Quota: Who is eligible to stand for top positions?", Al-Raida.

Bozena, Christina Welborne. 2010. The Strategic Use of Gender Quotas in the Arab World, Washington: IFES. 
Bono, Irene. 2010. Le "phénomène participatif" au Maroc à travers ses styles d'action et ses normes, Les Etudes du CERI, 166, Paris: Centre d'études et de recherches internationales, Sciences Po.

Catusse, Myriam, Rafaele Catedra, and M'hammed Idrissi Janati. 2007. "Decentralisation and its Paradoxes in Morocco". In Cities of the South, edited by Barbara Driesken, Franck Mermier, and Heiko Wimmen, 113-135. London: Saqi Books.

Clark, Janine. 2012. "A Call for the Quotidian, the Local, the Peripheries and a Spatial Dimension”. In Arab Uprisings. New Opportunities for Political Science, POMEPS Briefings 12, June, 17-19.

Darhour, Hanane, and Drude Dahlerup. 2013. "Sustainable Representation of Women through Gender Quotas: A Decade's Experience in Morocco". Women's Studies International Forum 41, 132-142.

Desrues, Thierry. 2013. "Mobilizations in a hybrid regime: The $20^{\text {th }}$ February Movement and the Moroccan regime", Current Sociology 61, 409-423.

Desrues, Thierry, and Said Kirhlani. 2010. "Dix ans de monarchie exécutive et citoyenne: élections, partis politiques et défiance démocratique". L'Année du Maghreb VI, 319-354.

Diamond, Larry. 2002. “Thinking about Hybrid Regimes”. Journal of Democracy 13 (2), 21 35.

Filali-Ansary, Houda. 2009. "Elles ont été candidates aux communales, elles racontent". La Vie Economique, July 13.

Gandhi, Jennifer, and Ellen Lust-Okar. 2009. "Elections under Authoritarianism". Annual Review of Political Science 12, 403-422.

Haut Commissariat au Plan, Enquête nationale auprès des institutions sans but lucratif, 2011.

Herzog, Hanna. 1987. "The Election Campaign as a Liminal Stage: Negotiations over Meanings". The Sociological Review 35 (3), 559-574.

Iraki, Aziz. 2005. "Du renouvellement des élites urbaines au Maroc. Élites urbaines, territoire et système politique local". Annuaire de l'Afrique du Nord, 81-95.

Karam, Azza, and Joni Lovenduski. 2005. "Women in Parliament: Making a Difference". In Women in Parliament: Beyond Numbers, edited by Julie Ballington, and Azza Karam, 187213. Stockholm: IDEA.

Krook, Mona Lena. 2009. Quotas for Women in Politics: Gender and Candidate Selection Reform World Wide. Oxford: Oxford University Press.

Lidell, James. 2009. "Gender Quotas in Clientelist Systems: The Case of Morocco's National List”. Al-Radia, no. 126-127, Summer/Fall, 79-86. 
Lust-Okar, Ellen. 2006. "Elections under Authoritarianism: Preliminary Lessons from Jordan”. Democratization 13 (3), 456-471

Lust Ellen, 2009. "Competitive Clientelism in the Middle East". Journal of Democracy 20 (3), 122-135.

Maghraoui, Driss. 2011. "Constitutional Reforms in Morocco: Between Consensus and Subaltern Politics”. Journal of North African Studies, 16 (4), 679-699

Moghadam, Valentine M. 2009. "Women, Politics, and Gender Quotas". Al-Raida, no. 126127, Summer/Fall, 18-27.

Royaume du Maroc, and USAID. 2010. Rapport relatif aux résultats du diagnostic participatif sur l'état de l'exercice de la fonction d'élue et de la participation des femmes à la gouvernance locale, (unpublished report), Rabat.

Sabbagh, Amal. 2007. “Overview of Women's Political Representation in the Arab Region: Opportunities and Challenges". In The Arab Quota Report: Selected Case Studies, edited by IDEA, 7-18.

Sater, James N. 2007. "Changing Politics from Below? Women Parliamentarians in Morocco". Democratization 14 (4), 723-742.

Schedler, Andreas, ed. 2006. Electoral Authoritarianism. The Dynamics of Unfree Competition, Boulder: Rienner Publ.

Tozy, Mohamed. 1999. Monarchie et islam politique au Maroc, Paris: Presses de Sciences Po.

Tozy, Mohamed. 2008. "Islamists, Technocrats and the Palace". Journal of Democracy 19 (1), 34-41.

Tozy, Mohamed. 2010. "Introduction”. In Elections au Maroc. Entre partis et notables (20072009), edited by Mohamed Tozy, 11-25. Casablanca: CM2S/Konrad Adenauer Fondation.

Vairel, Frédéric. 2009. “La 'liste nationale': un quota électoral pour quoi faire?”. In Terrains de campagne au Maroc. Les élections législatives de 2007, edited by Lamia Zaki, 135-157. Paris: Karthala.

Waterbury, John. 1997, "Fortuitous byproducts”, Comparative Politics, 29 (3), 383-402.

Yadav, Stacey Philbrick. 2012. "Segmented Publics and Islamist Women in Yemen: Rethinking Space and Activism". Journal of Middle East Women's Studies 6 (6), 1-30.

Zaki, Lamia, ed. 2009. Terrains de campagne au Maroc. Les élections législatives de 2007, Paris : Karthala. 